\title{
CORPORATE SOCIAL RESPONSIBILITY PRACTICES: THE EXAMPLES OF LATVIA AND UKRAINE
}

\author{
Iryna Vasylchuk ${ }^{1}$, Kateryna Slyusarenko ${ }^{2}$, Inta Kotane ${ }^{3}$ \\ ${ }^{1}$ DSc., professor, State University of Economics and Technology, Kryvyi Rih, Ukraine, \\ e-mail: vasylchuk ip@kneu.dp.ua \\ ${ }^{2} \mathrm{PhD}$, associate professor, State University of Economics and Technology, Kryvyi Rih, \\ Ukraine, e-mail: slusarenko kv@kneu.dp.ua \\ ${ }^{3}$ Mg.oec., lecturer, researcher, Rezekne Academy of Technologies, Rezekne, Latvia, \\ e-mail: inta.kotane@rta.lv
}

Received: 17 August 2020 / Revised: 27 August / Accepted: 18 September 2020 / Published: 30 November 2020

\begin{abstract}
Corporate social responsibility (CSR) as a good business practice and an organized movement develops and gains increasing support not only among entrepreneurs and businesspersons but also among consumers choosing goods and services from reputable enterprises that implement generally accepted business ethics in their daily operation. The problem of CSR has become urgent in the context of ensuring economic and sustainable business development. Increasing attention is paid to raising the competitiveness and efficiency of business through the principles of CSR. The latest research on reputation and CSR in Latvia shows that there are few entrepreneurs, national institutions and members of the public in Latvia who understand the basics of CSR and support the manifestations thereof. In Ukraine, CSR practices of companies are also at the initial stage of their development, they are carried out epidemically, and only large companies have sustainable development strategies and publish non-financial reports. The aim of the research is to assess CSR practices in Ukraine and Latvia. General scientific research methods were used in the given research, namely: the monographic and descriptive methods and comparative analysis. The results of the research revealed that socially responsible entrepreneurship related to the principles of sustainable development, i.e. meeting current needs without compromising the needs of future generations. Sustainable development is characterized by three interrelated dimensions: environmental, economic and social, through which socially responsible entrepreneurship could be assessed.
\end{abstract}

Keywords: corporate social responsibility, sustainable development, index, rating. JEL code: M14, Q01.

\section{Introduction}

CSR as a good business practice and an organized movement has been developing and gaining increasing support since the 1990s not only among entrepreneurs and businesspersons but also among consumers choosing goods and services from reputable enterprises that implement generally accepted business ethics in their daily operation. Achieving high competitiveness and productivity is not possible without the involvement of the enterprises in international and global processes; therefore, CSR has become a part of corporate strategies in the last decade (Labklājības 
ministrija, 2019).

The authors believe that the problem of CSR has become urgent in the context of ensuring economic and sustainable business development. Increasing attention is paid to raising the competitiveness and efficiency of business through the principles of CSR.

However, there are few entrepreneurs, national institutions and members of the public in Latvia who understand the basics of CSR and support the manifestations thereof (Labklājība ministrija, 2019). In Ukraine, CSR practices of companies are also at the initial stage of their development, they are carried out epidemically, and only large companies have sustainable development strategies and publish non-financial reports.

The aim of the research is to assess CSR practices in Ukraine and Latvia.

Specific research tasks:

1. To examine the theoretical aspects of corporate social responsibility;

2. To assess the implementation of CSR in enterprises in Ukraine and Latvia.

The research used general scientific research methods: theoretical generalization and comparison - in the study of theoretical aspects of CSR; comparative analysis - in the research of the best CSR practices, the sustainable development ratings principles and indices methodologies; analogies and extrapolations - in assessing the possibilities of using the world CSR experience in the realities of Ukraine and Latvia; logical generalization - in the formulation of conclusions.

\section{Theoretical aspects of corporate social responsibility}

The concept of corporate social responsibility (CSR) dates back to the 1950s. Howard R. Bowen - considered the pioneer of CSR - defined CSR as "the obligations of businessmen to pursue those policies, to make those decisions, or to follow those lines of action which are desirable in terms of objectives and values of our society" (Bowen, 1953). Dahlsrud (2008), after analysing 37 different definitions of CSR given in a time span from 1980 until 2003, concluded that the majority of scholars focused on five key organizational obligations when defining CSR: stakeholder, social, economic, voluntariness, and environmental. The researcher claimed that social obligations were among the most usable terms in the CSR definitions after stakeholder obligations (Dahlsrud, 2008). The stakeholders, being more cognizant, have been progressively demanding information on non-financial performance of companies. Sustainability reporting (SR) is, thus, a pertinent issue for companies today. It is defined by the Global Reporting Initiative (GRI) as "the practice of measuring, disclosing and being accountable to internal and external stakeholders for organizational performance toward the goal of sustainable development" (GRI, 2011). 
In its resolutions of 6 February 2013 on, respectively, 'CSR: accountable, transparent and responsible business behaviour and sustainable growth' and 'CSR: promoting society's interests and a route to sustainable and inclusive recovery', the European Parliament acknowledged the importance of businesses divulging information on sustainability such as social and environmental factors, with a view to identifying sustainability risks and increasing investor and consumer trust. Indeed, disclosure of non- financial information (NFI) is vital for managing change towards a sustainable global economy by combining long-term profitability with social justice and environmental protection (European Union, 2014). Non-financial reporting is a growing topic, and the adoption of the EU Directive 2014/95/EU on NFI is increasing the use of this reporting. One of the most distinctive elements of guidelines and standards that are widely used to draw-up reports on NFI is sustainability performance indicators (SPIs) (Raucci, Tarquinio, 2020).

Researchers revealed that CSR positively affects corporate financial performance (CFP) (Devie et al., 2018); customers' CSR awareness levels have a positive impact on company image and reputation, but the customers' perception of a company's CSR motives has a negative impact on the company's image and reputation (non-financial performance) (Nyarku, Ayekple, 2019); they created the sustainability reporting index framework, which is built on the basis of the stakeholder relationship theory and is focused on three main dimensions (social, economic and environmental) (Firmialy, Nainggolan, 2019). Arrigo (2012) concluded that the main output of corporate responsibility management is solid stakeholder relationships resulting in: employee attraction and motivation, a powerful brand, enhanced consumer perceptions, profitability. Through the corporate responsibility management process, fast fashion companies can achieve sustainable development". Gunawan and Tin (2019) analysed accounting research developments in the area of CSR) in Indonesia for the period 20122016 and discovered that ... (2) The most widely used variable associated with CSR was financial performance; (3) More than 80 per cent of the CSR research used annual reports as the source of data with only 19.23 per cent using sustainability reports; (4) 65.38 per cent of the CSR disclosure measurements referred to used other CSR disclosure lists, other than the Global Reporting Initiative (GRI). The sustainability and responsibility of corporate strategic management has become an important issue in recent years (Stiglbauer, 2011). The Sustainable Development Goals are the blueprint to achieve a better and more sustainable future for all. They address the global challenges we face, including those related to poverty, inequality, climate change, environmental degradation, peace and justice. The 17 Goals are all interconnected, and in order to leave no one behind, it is important that we achieve them all by 2030 (United Nations). 
Businesses have a vital role to play in the sustainability transition. Over the last decades, both on a voluntary basis and spurred on by public authorities, an ever-growing number of companies have made environmental and social responsibility a core part of their corporate missions. More and more companies see the Sustainable Development Goals (SDGs) as an integral part of their competitiveness and growth strategy. They have understood that responsible business can lead to more sustainable profits and growth, new market opportunities, and long-term value for shareholders. In 2017, 78\% of the world's top companies included CSR in their annual reporting (European Commission, 2019).

Corporate social responsibility is becoming an integral part of business for more and more companies. The concept of corporate social responsibility includes seven main aspects: corporate governance, human rights, labour relations, the environment, honest operating practices, consumer relations, community development. Summing up, it should be admitted that corporate social responsibility is not just the company's responsibility to stakeholders, to society as a whole, not just a set of principles according to which the company builds its business processes, but the real worldview of beneficiaries introduced by social projects that are really useful for local communities. This is the philosophy of organizing business and social activities, which is followed by companies which care about their development, about ensuring a decent standard of living for people, about the development of society as a whole and the preservation of the environment for future generations.

\section{Main research findings Latvia}

According to the Employers Confederation of Latvia (LDDK), CSR is a philosophy of voluntary action and a way of affirming entrepreneurial values to society through building relationships among entrepreneurs, enterprises and influential audiences, which involves sustainable development and resource maintenance for future generations (LDDK, 2010). In 2010, a memorandum on the principles of CSR in Latvia was signed by 22 organizations representing the public, private and non-governmental sectors. The partners agreed to cooperate in the implementation, improvement and assessment of the principles of CSR.

In 2011, the LDDK established a CSR platform. The CSR platform is the main forum for CSR experts. The main purpose of the platform is to facilitate the exchange of expert experience and promote the development of a consolidated position of employers on CSR, referring to the CSR memorandum, as well as to give recommendations to public sector 
organizations after assessing best CSR practices of enterprises. The platform ensures the implementation of CSR policies at the local, regional, national and international levels (LDDK, 2014).

Based on the need to assess progress in the field of CSR as stated by the Memorandum, the LDDK created a sustainability index for the implementation of it in cooperation with the Free Trade Union Confederation of Latvia (LBAS), which involved experts from various fields of sustainability. This was the only initiative of this kind in the world where business and employee representatives joined their efforts (Pārvaldība, n.d.).

The sustainability index is a strategic management tool based on an internationally recognized methodology that helps Latvian enterprises to diagnose the sustainability of their operation and the levels of their corporate responsibility. At the same time, the index provides the public as well as governmental and non-governmental organizations with objective criteria to praise and support the enterprises that help strengthen the economy of Latvia in a long term. The methodology for the sustainability index of Latvian enterprises is based on the most influential global indexes the Dow Jones Sustainability Index and the Business in the Community CR Index - and takes into account the corporate responsibility standard ISO 26000 and the Global Reporting Initiative (GRI) G3 guidelines. The localized index assesses the performance of enterprises based on economic, social and environmental problems relevant to Latvia while also representing an internationally recognized understanding of the criteria of corporate responsibility and sustainability (Par iniciativvu, n.d.).

In order for an enterprise to get its sustainability index score, it must register on the website ilgtspejasindekss.lv, sign a document certifying that the enterprise has no insolvency status and tax debts and employs no unregistered employees as well as perform a self-assessment. The Expert Council has the right to verify the information provided by the enterprise with the State Revenue Service and the State Labour Inspectorate. A sustainability index questionnaire contains more than 100 criteria grouped in five sections, and each section has its own index weight determined by experts according to its role in the overall sustainability of the enterprise: the strategy $(15 \%)$, the working environment $(25 \%)$, market relations $(20 \%)$, the public (15\%) and the environment (25\%). To exclude any subjectivity in the assessment, each criterion establishes the fact - whether or not the enterprise implements a particular practice. ... Just like in the world, the enterprise's website is increasingly used as an information channel to inform its stakeholders about the progress made in the field of corporate sustainability and responsibility (LBAS, n.d.).

Based on index scores, enterprises are divided into four categories: platinum (index score above 90\%), gold (index score from 80 to $89.9 \%$ ), 
silver (index score from $60 \%$ to $79.9 \%$ ) and bronze (index score from 40 up to $59.9 \%$ ). For example, the enterprises that reach the platinum level in the sustainability index have fully integrated corporate responsibility into their operation and have appointed those responsible at both the supervisory board and the executive board levels. Such enterprises systematically collect data and perform assessments of their impacts, which indicates a 3-4-year steady improvement in their performance in all the areas where the enterprise makes some impact. Such enterprises operate and report on their activities with a high level of transparency and influential audience involvement (LBAS, n.d.).

The results of the 2020 sustainability index assessment done by the Institute of Corporate Sustainability and Responsibility (InCSR) show that the understanding of Latvian enterprises and organizations about the principles of responsibility and sustainability increased. This year, the performance of the institute's members reached $75.4 \%$, which was almost $30 \%$ higher than that reported by the first sustainability index assessment, which was done in 2010. The minimum sustainability index threshold was reached by 62 participants. Of them, 19 organizations qualified for the high platinum category (e.g. the JSC Latvian Railways, the JSC SEB bank etc.) (InCSR, 2020).

As mentioned above, the sustainability index is based on selfassessments of enterprises; as a result, the enterprises that are liquidated a few months after being rated for sustainability sometimes receive high ratings in the index. Sustainability index coordinator D.Helmane explains that "The index is based on a self-assessment, in which the enterprise confirms each answer by a document or publicly available information about its performance. Prior to this, all the participants sign a statement that the information provided is true. If the enterprise does not provide true information or the documents are drawn up but do not work in life, it is the enterprise's responsibility. Throughout these years, we have repeatedly emphasized that the stakeholders (employees, customers, the public etc.) should respond if they notice that an enterprise's real performance differs from that reported by the sustainability index or other assessments" (Pietiek, 2020).

Feedback from the participants (enterprises) shows that the sustainability index:

- helps enterprises to develop, implement and assess responsible business practices;

- helps to integrate the principles of corporate responsibility into the business strategy;

- provides a valuable analysis, pointing to both the most successful performance and development opportunities; 
- offers an opportunity to track changes in the performance, as well as compare it with the performance of other companies;

- provides an opportunity to use the results of the index in the enterprise's communication (Ieguvumi, n.d.)

To encourage Latvian entrepreneurs to implement CSR principles in their businesses as well as to perform a sustainability index assessment, it would be necessary to create a legal framework for identifying CSR activities and the benefits achieved.

\section{CSR practices in Ukraine}

In Ukraine, CSR has not yet become a mass phenomenon - mainly this is the inheritance of international companies, their divisions and large domestic public companies. And only since 2015 after the adoption of the Sustainable Development Goals at the global level (SDG-2030), and subsequently after the adoption of a set of measures regarding the development of the "Strategy for the Sustainable Development of Ukraine until 2030," the Decree of the President of Ukraine "On the Goals for the Sustainable Development of Ukraine for the Period until 2030," more and more companies, including medium-sized ones, began to actively implement the principles of CSR in their activities. According to the survey conducted in June 2020, 83\% of Ukrainian companies implemented CSR polices, and 52\% of companies had approved CSR strategies (Центр «Розвиток КСВ», 2020; Зінченко, А., Саприкіна, 2018). Some Ukrainian companies had sustainable development strategies agreed with SDG-2030; others continued to implement previously adopted tasks within the framework of the CSR policy.

Companies review their CSR activities and put into strategy the achievement of certain SDG corresponding to the profile of their activities. Most often, their activities are focused on social aspects (staff development), individual environmental issues and solving the problems of local communities in business locations. At the same time, surveys show that the owners of a significant number of small companies do not yet realize the need to introduce CSR into their strategic and operational activities; they either do not understand how to do this, or have no motivation.

The elaboration of sustainable development strategies and CSR of Ukrainian companies is based on the Principles of Sustainable Development of the UN Global Compact, ISO 26000 and the GRI. The results of CSR activities are published either in the form of non-financial statements, or most often in the form of information on corporate websites.

There are different approaches to the choice of topics for assessing the sustainable development of companies and their implementation of CSR practices. In Ukrainian practice, methods for rating the sustainable 
development of companies and the state of their CSR based on the index method have become widespread. Researchers' proposals for assessing CSR have more different methodological approaches. Generally, the following evaluation areas are identified: (1) social investment (and within its framework social policy), (2) efficiency/effectiveness of CSR, (3) CSR practices. Thus, Tovma (Товма, 2009) proposes to determine the rating of CSR using an indicator of the integrated efficiency of the social programme, taking into account quantitative coefficients (wage growth, staff turnover, admission of young specialists, etc.) and the overall qualitative indicator of CSR, which consists of partial quality indicators (collective agreement, social report, etc.). Berezina (2012) proposes a method for determining the rating of social responsibility of a corporation in the field of labour relations based on a quantitative assessment of CSR. Vasylchuk (2016) proposed to develop an integral indicator that is the index for assessing the performance of CSA (corporate social activity) of domestic companies. The author proposed the following key topics for the evaluation methodology: (1) general information about the organization of CSA management and sustainable development management; 2) social aspects (oriented to the internal perspective); 3) environmental aspects (oriented to the internal and external perspective); 4) corporate citizenship and charity (oriented towards the external perspective); 6) stakeholder management; 7) business ethics and compliance control. All the authors try to reflect more fully various aspects of the activities of corporations, which better corresponded to the peculiarities of Ukrainian realities, taking into account world experience.

Professional non-governmental organizations have also joined the assessment of CSR and sustainable corporate development. So, since 2011 the Development of Corporate Social Responsibility Centre has begun to calculate the Index of transparency of the companies of Ukraine (Зінченко, Резнік, Саприкіна, 2018) on introduction of the practices of CSR and informing the public, including the main stakeholders of the company, about the policy and practices in the sphere of CSR. The main feature of this index is that the object of the assessment is the company's website, and any user of the Internet can verify the validity of its results. Until 2018, the Index was the only tool for monitoring the development of corporate social responsibility in Ukraine on the example of the 100 largest companies in Ukraine.

Today, the most famous rating is the Sustainable Ukraine Rating, offered by Premier Business Consulting \& Communications, the initiator of the Sustainable Ukraine project. According to its founders, this is the first professional rating of corporate sustainability of Ukrainian companies, based on leading world practices with a focus on the investment attractiveness of enterprises. The mission of the rating is to create prerequisites for the sustainable development of Ukraine, the growth of competitiveness and the 
attractiveness of socially responsible business behaviour and, subsequently, the construction of the society according to a qualitatively new model. The Sustainable Ukraine Rating (Sustainable Ukraine, 2019) provides the unified ESG coordinate system for assessing and comparing the quality of corporate governance in companies, as well as their ability to influence society, manage non-financial risks and opportunities, and ensure their sustainable development. In addition, the analysis of the rating results will make it possible to predict the sustainable development vector of the entire Ukrainian business environment and the country as a whole. The main topics and areas included 4 main ones: financial and economic sphere, social sphere, environmental sphere, corporate governance sphere.

Therefore, it is advisable to get acquainted in more detail with the experience of CSR "best practices" of advanced Ukrainian companies that meet the criteria for sustainability. For such a study, we selected leading companies from the Sustainable Ukraine Rating, namely SE NNEGC (State enterprise National Nuclear Energy Generating Company of Ukraine) Energoatom, CJSC (Closed Joint Stock Company) Ukrhydroenerho, LLC ( Ltd company) Kernel and FE (Foreign Enterprise) Coca-Cola Ukraine. For our analysis, we have chosen the main important aspects of the organization of the implementation of the strategy for the sustainable development of companies, namely:

1) the company's goal in the sphere of sustainable development (or CSR);

2) CSR main fields of activity or specific Sustainable Development Goals;

3) peculiarities of the implementation of the sustainable development strategy or CSR policy;

4) transparency, openness and ease of access to company information and reports;

5) features of relationships with stakeholders.

The information on the peculiarities of sustainable development practices of NNEGC Energoatom and CJSC Ukrhydroenergo is given in Appendix 1. Both companies belong to state-owned companies and work in the energy sector. The results of the comparative analysis show that both companies demonstrate a model for the implementation of sustainable development goals, the site has a separate section (or page) devoted to CSR and sustainable development, they submit non-financial reports, aim to achieve a sustainable future by introducing innovation into their areas of activity and have an action plan in three areas - environmental, economic and social ones. It should be noted that the companies work on their image and take part in various competitions and ratings.

Next, we compare the features of the CSR policy for the other two leaders of the Sustainable Ukraine Rating, which belong to the food industry - Kernel LLC and Coca-Cola Ukraine, which are a part of the international group 
(Appendix 2). Thus, the comparative analysis shows that both companies pay considerable attention to social policy and the interaction with local communities, which allows them to ensure the loyalty of territorial communities and consumers. Both companies have a special marketing policy as a responsible producer, offer only high-quality and safe products; besides, Kernel is also distinguished by its environmental friendliness.

Summarizing the above, the given data on activities allow us to say that the above-mentioned companies demonstrate "best practices", which can serve as the basis for the development of sustainable development strategies for other domestic companies. There are the following most significant advantages of CSR for business development: the integration of CSR into the operating activities of companies and the introduction of CSR practices improves the company's reputation and brand, helps to develop and open new markets and business lines. Companies gain access to socially responsible investments, in the distribution of which investors take into account the indicators that characterize the company's activities in the field of CSR and sustainable development.

Recently, there has been a certain shift in consumer priorities: neither the price, nor the quality, nor the functionality of the product allows the manufacturer to stand out from the competition. The emotional involvement of consumers and common values are something that is quite difficult to develop and imitate, and if they are ingrained, it is difficult to give them up. In socially responsible companies, there is an increase in sales and in customer loyalty. Consumers want to know that products are made with an understanding of environmental responsibility as well as other social aspects. Some consumers are even willing to pay more for "responsible" products.

Thanks to the introduction of CSR practices in the field of ecology, companies have the opportunity to reduce operating costs as well as to improve the productivity and quality of their products and services. For example, by reducing the production waste or their recycling, increasing the energy efficiency or selling the recycled materials.

All of the listed above ultimately affects the increase in profits and the speed of its growth, as well has positive impact on the growth of the company's competitiveness.

In the context of staff hunger, which is observed in almost all sectors of the economy, the implementation of sustainable development strategies of companies affects the expansion of opportunities to attract and retain employees: people prefer to work in companies whose values coincide with their own. 


\section{Conclusions and suggestions}

The concept of corporate social responsibility includes seven main aspects: corporate governance, human rights, labour relations, the environment, honest operating practices, consumer relations, community development.

In 2010, a memorandum on the principles of CSR in Latvia was signed by 22 organizations representing the public, private and non-governmental sectors. Based on the need to assess progress in the field of CSR as stated by the Memorandum, the LDDK created a sustainability index for the implementation of it in cooperation with the LBAS, which involved experts from various fields of sustainability. This was the only initiative of this kind in the world where business and employee representatives joined their efforts. The results of the 2020 sustainability index assessment done by the Institute of Corporate Sustainability and Responsibility (InCSR) show that the understanding of Latvian enterprises and organizations about the principles of responsibility and sustainability increased.

To encourage Latvian entrepreneurs to implement CSR principles in their businesses as well as to perform a sustainability index assessment, it would be necessary to create a legal framework for identifying CSR activities and the benefits achieved.

To assess the sustainable development of companies and the state of their CSR in Ukraine, the method of rating assessment based on the index method has become widespread. The most famous is the "Sustainable Ukraine" Rating, offered by Premier Business Consulting \& Communications, the initiator of the Sustainable Ukraine project. The research conducted showed that, unlike foreign corporations, for Ukrainian companies, social responsibility is mainly one-time action, aimed at improving their reputation, and is provided without the desire (time and opportunity) to consider this process as long and continuous. It was revealed that the introduction of "best practices" and principles of CSR in the activities of Ukrainian companies has a number of advantages.

The more systematic introduction of CSR into the practice of Ukrainian companies will not only significantly improve the environmental and socioeconomic situation in places where companies are present but also increase their profitability and investment attractiveness due to the opportunities provided by CSR.

\section{References}

1. Arrigo, E. (2013). Corporate responsibility management in fast fashion companies: the Gap Inc. case". Journal of Fashion Marketing and Management. 17(2), 175-189. Retrieved from https://doi.org/10.1108/JFMM-10-2011-0074 
2. Berezina A.Yu. (2012). Quantitative assessment of social responsibility of corporations. Bulletin of the Ukrainian academy of banking. 1(32), 97-101. Retrieved from https://essuir.sumdu.edu.ua/bitstreamdownload/123456789/57434/5/Berezina social responsibility.pdf

3. Bowen, H.R. (1953). Social Responsibilities of the Businessman. Harper and Row, New York, NY.

4. Coca Cola Hellenic Bottling Company Ukraine (n.d.). Наш підхід до сталого розвитку. $\quad$ Retrieved from https://ua.cocacolahellenic.com/ua/sustainability/sustainability-approach-andperformance/sustainability-approach/

5. Dahlsrud, A. (2008). How Corporate Social Responsibility Is Defined: An Analysis of 37 Definitions. Corporate Social Responsibility and Environmental Management, 15, 113. Retrieved from http://dx.doi.org/10.1002/csr.132

6. Devie, D., Liman, L.P., Tarigan, J., Jie, F. (2018), Corporate social responsibility, financial performance and risk in Indonesian natural resources industry. Social Responsibility Journal. 16(1), 73-90. Retrieved from https://doi.org/10.1108/SRJ-06$\underline{\text { 2018-0155 }}$

7. Energoatom (2018). Energoatom non-financial report 2018. Retrieved from http://nfr2018.energoatom.kiev.ua/en/index.php

8. European Commission (2019). Reflection Paper Towards a Sustainable Europe by 2030. Retrieved from https://ec.europa.eu/commission/sites/betapolitical/files/rp sustainable europe 30-01 en web.pdf

9. European Union (2014). Directive 2014/95/EU of the European Parliament and of the Council of 22 October 2014 amending Directive 2013/34/EU as regards disclosure of non-financial and diversity information by certain large undertakings and groups. Retrieved from https://eur-lex.europa.eu/legalcontent/EN/TXT/PDF/?uri=CELEX:32014L0095\&from=EN

10. Firmialy, S.d., Nainggolan, Y.A. (2019). Constructing the ideal SRI (sustainability reporting index) framework for Indonesian market: combined perspectives from rating agencies, academics, and practitioners. Social Responsibility Journal. 15(5), 573-596. Retrieved from https://doi.org/10.1108/SRJ-07-2016-0128

11. GRI (2011). Sustainability Reporting Guidelines. Retrieved from https://www.yumpu.com/en/document/read/21481965/g31-sustainabilityreporting-guidelines-global-reporting-initiative

12. Gunawan, J., Tin, S. (2019). The development of corporate social responsibility in accounting research: evidence from Indonesia. Social Responsibility Journal, 15(5), 671-688. Retrieved from https://doi.org/10.1108/SRJ-03-2018-0076

13. Ieguvumi (n.d.). Ilgtspējas indekss. Pieejams: https://www.ilgtspeja.lv/ieguvumi/

14. InCSR (2020). Ilgtspējas indekss $2020 . \quad$ Pieejams https://www.incsr.eu/novertejumi/ilgtspejas-indekss/ilgtspejas-indekss-2020/

15. Kernel (n.d.). Політика сталого розвитку і корпоративної соціальної відповідальності. Retrieved from https://www.kernel.ua/ua/sustainabledevelopment/

16. Labklājība ministrija (2019). Korporatīvā sociālā atbildība. Pieejams: http://www.lm.gov.lv/lv/index.php?option=com content\&view=article\&id=80169

17. LBAS (n.d.) Ilgtspējas indekss. Žurnāls Ilgtspējas indekss, speciālpielikums. Pieejams http://arodbiedribas.lv/wpcontent/uploads/2019/11/ilgtspejas indekss parskats.pdf

18. LDDK (2010). Memorands par korporatīvās sociālās atbildības principiem. 
Korporatīvās sociālās atbildības platforma. Pieejams http://www.lddk.lv/wpcontent/uploads/2016/04/memorands-par-ksa-principiem-latvij 2010.pdf

19. LDDK (2014). Korporatīvās sociālās atbildības platforma. Pieejams http://www.lddk.lv/pakalpojums/korporativas-socialas-atbildibas-platforma/

20. Nyarku, K.M., Ayekple, S. (2019). Influence of corporate social responsibility on nonfinancial performance. Social Responsibility Journal. 15(7), 910-923. Retrieved from https://doi.org/10.1108/SRJ-04-2017-0059

21. Par iniciatīvu (n.d.) Ilgtspējas indekss. Pieejams https://www.ilgtspeja.lv/pariniciativu/

22. Pārvaldība (n.d.). Ilgtspējas indekss Pieejams https://www.ilgtspeja.lv/parvaldiba/

23. Pietiek (2020). Dīvainā "Ilgtspējas indeksa" pamatā esot...uzñēmumu pašnovērtējums. Pieejams:

https://pietiek.com/raksti/divaina ilgtspejas indeksa pamata esot uznemumu pas novertejums?nomob

24. Raucci, D., Tarquinio, L. (2020). Sustainability Performance Indicators and NonFinancial Information Reporting. Evidence from the Italian Case. Administrative Sciences, 10(1), 1.-17.

25. Stiglbauer, M. (2011). Strategic stakeholder management by corporate social responsibility: Some conceptual thoughts. Risk Governance and Control: Financial Markets \& Institutions, 1(2), 45-55. Retrieved from http://dx.doi.org/10.22495/rgcv1i2art4

26. Sustainable Ukraine (2019). Sustainable Ukraine methodology. Retrieved from https://sustainableukraine.com/ua/methodology.html

27. United Nations (n.d.) About the Sustainable Development Goals. Retrieved from https://www.un.org/sustainabledevelopment/sustainable-development-goals/

28. Vasylchuk, I. P. (2016). Financial determinants of effectiveness of corporate social activity of the companies in Ukraine: technique and results of the empirical research. Business-Inform, 1, 153-162. $\quad$ Retrieved from http://nbuv.gov.ua/UJRN/binf 2016125

29. Зінченко, А., Резнік, Н., Саприкіна, М. (Укладачі) (2018). Індекс прозорості сайтів українських компаній - 2017. К.: Видавництво «Юстон». Retrieved from http://old.csr-ukraine.org/wp-content/uploads/2018/10/Transp Index 2018 preview.pdf?fbclid=IwAR3t8Twai7 wBdLHAsFTZEZnjI3D4L6yOc3rOtF48UnMloCbGh8iVHwNZIs

30. Зінченко, А., Саприкіна, М. (Укладачі) (2018). Розвиток КСВ в Україні: 2010-2018. К.: Видавництво «Юстон». Retrieved from http://old.csr-ukraine.org/wpcontent/uploads/2018/10/CSR 2017 reserch-1.pdf

31. Товма, Н.A. (2009). Рейтинговые Показатели КСО. Доступно: http://www.rusnauka.com/5 NMIV 2009/Economics/40769.doc.htm

32. Укргідроенерго (n.d.) Сталий розвиток ПрАТ «Укргідроенерго» Retrieved from https://uhe.gov.ua/stalyy rozvytok

33. Центр «Розвиток КСВ» - Офіційний сайт Retrieved from https://csr-ukraine.org/ 
Best CSR practices of NAEK Energoatom and CJSC Ukrhydroenergo

Appendix 1

(compiled by the authors based on Energoatom, 2018; Укргідроенерго , n.d.)

\begin{tabular}{|c|c|c|c|c|}
\hline Company & $\begin{array}{l}\text { Company's goal in implementing } \\
\text { sustainable development strategy }\end{array}$ & $\begin{array}{l}\text { CSR main fields of activity } \\
\text { or specific Sustainable } \\
\text { Development Goals }\end{array}$ & $\begin{array}{l}\text { Peculiarities of strategy } \\
\text { implementation }\end{array}$ & $\begin{array}{c}\text { Transparency and } \\
\text { openness }\end{array}$ \\
\hline $\begin{array}{l}\text { SE NNEGC } \\
\text { Energoatom }\end{array}$ & $\begin{array}{l}\text { The Company aims to maximize its } \\
\text { contribution to the sustainable } \\
\text { development of society, taking into } \\
\text { account all economic, social and } \\
\text { environmental aspects. Among the } \\
\text { key fields of the Company's activity } \\
\text { are responsible attitude to } \\
\text { production, society and the } \\
\text { environment, as well as creating } \\
\text { decent working conditions for the } \\
\text { Company's workers and caring for } \\
\text { future generations. }\end{array}$ & $\begin{array}{l}\text { The three Sustainable } \\
\text { Development Goals } \\
\text { Goal No. 7: Ensuring access to } \\
\text { affordable, reliable, sustainable } \\
\text { and modern energy sources for } \\
\text { everybody; } \\
\text { Goal No. 9: Putting in place } \\
\text { sustainable infrastructure, } \\
\text { promoting comprehensive and } \\
\text { sustainable industrialization and } \\
\text { innovation; } \\
\text { Goal No. 13: Taking urgent action } \\
\text { to combat climate change and its } \\
\text { effects. }\end{array}$ & $\begin{array}{l}\text { One of the main areas of CSR } \\
\text { activity is work with staff, as } \\
\text { well as the implementation of } \\
\text { educational projects, the } \\
\text { development of the social } \\
\text { sphere in satellite cities, } \\
\text { concern for the environment } \\
\text { and ecology and corporate } \\
\text { volunteering. }\end{array}$ & $\begin{array}{l}\text { The Company was awarded } \\
\text { in the competition } \\
\text { Deloitte Sustainability } \\
\text { Report Award, The Green } \\
\text { Frog Award (GFA) } 2018 \\
\text { for demonstrating the best } \\
\text { indicators of sustainability } \\
\text { and strategic commitments } \\
\text { published in non-financial } \\
\text { reports. }\end{array}$ \\
\hline \begin{tabular}{|l|} 
CJSC \\
Ukrhydroenerho
\end{tabular} & $\begin{array}{l}\text { The company's CSR strategy is } \\
\text { aimed at voluntary integration of } \\
\text { social and environmental aspects in } \\
\text { the production and economic } \\
\text { activities of the enterprise and their } \\
\text { implementation in cooperation } \\
\text { with stakeholders. The company's } \\
\text { CSR is aimed at improving the social } \\
\text { ecosystem in places where the } \\
\text { company is present. }\end{array}$ & $\begin{array}{l}\text { The Company's activities are } \\
\text { guided by CSR 2030, which were } \\
\text { approved at the UN Summit on } \\
\text { Sustainable Development in } 2015 \\
\text { and the 10th principles of the UN } \\
\text { Global Compact. }\end{array}$ & $\begin{array}{l}\text { 1. Increasing public confidence } \\
\text { in the company's activities. } \\
\text { 2. Introducing the principle of } \\
\text { environmental responsibility } \\
\text { and innovations into production } \\
\text { processes and projects. } \\
\text { 3. Creating a favourable } \\
\text { environment for realizing the } \\
\text { potential of the company's } \\
\text { employees. }\end{array}$ & $\begin{array}{l}\text { They regularly inform the } \\
\text { representatives of } \\
\text { stakeholders in a manner } \\
\text { that they understand the } \\
\text { results of their CSR } \\
\text { activities. }\end{array}$ \\
\hline
\end{tabular}


Appendix 2

Best Practices for Sustainable Company Development of LLC Kernel and Coca-Cola Beverages Ukraine

(compiled by the authors based on Kernel, n.d.; Coca Cola Hellenic Bottling Company Ukraine, n.d.)

\begin{tabular}{|c|c|c|c|c|}
\hline Company & $\begin{array}{l}\text { Company's goal in } \\
\text { implementing sustainable } \\
\text { development strategy }\end{array}$ & $\begin{array}{l}\text { CSR main fields of activity } \\
\text { or specific Sustainable Development Goals }\end{array}$ & $\begin{array}{l}\text { Peculiarities of strategy } \\
\text { implementation }\end{array}$ & $\begin{array}{l}\text { Transparency and } \\
\text { openness }\end{array}$ \\
\hline LLC Kernel & $\begin{array}{l}\text { The global goal is to } \\
\text { develop the society by } \\
\text { means of the voluntary } \\
\text { contribution of business to } \\
\text { the social, economic and } \\
\text { environmental spheres } \\
\text { related to the Company's } \\
\text { activities and achievement } \\
\text { of strategic goals. }\end{array}$ & $\begin{array}{l}\text { 1. The social goal is developing the potential of } \\
\text { people, ensuring labour and health protection, } \\
\text { creating conditions for the self-realization and } \\
\text { professional development of employees, } \\
\text { contributing to solving socially significant } \\
\text { problems and developing communities in the } \\
\text { regions of presence. } \\
\text { 2. The economic goal is to achieve maximum } \\
\text { profitability through the efficient use of } \\
\text { resources, the introduction of the latest } \\
\text { technologies, continuous improvement of } \\
\text { processes, transparent and open operation. } \\
\text { 3. The environmental goal is maximizing energy } \\
\text { efficiency, minimizing the negative impact on } \\
\text { the environment, reducing greenhouse gas } \\
\text { emissions, processing and minimizing waste, } \\
\text { preserving land properties for restoration. }\end{array}$ & $\begin{array}{l}\text { 1. Kernel is a responsible } \\
\text { employer } \\
\text { 2. Kernel is a social investor } \\
\text { and public leader } \\
\text { 3. Kernel is a reliable partner } \\
\text { 4. Kernel is a responsible } \\
\text { producer }\end{array}$ & $\begin{array}{l}\text { Kernel regularly } \\
\text { provides information } \\
\text { on sustainable } \\
\text { development and CSR } \\
\text { in the annual report in } \\
\text { accordance with the } \\
\text { requirements of the } \\
\text { current legislation and } \\
\text { international } \\
\text { standards, GRI } \\
\text { principles, and also } \\
\text { posts information } \\
\text { about the principles on } \\
\text { the Company's } \\
\text { corporate website and } \\
\text { other resources. }\end{array}$ \\
\hline $\begin{array}{l}\text { Company } \\
\text { Coca-Cola } \\
\text { Beverages } \\
\text { Ukraine }\end{array}$ & $\begin{array}{l}\text { CSR and sustainable } \\
\text { development } \\
\text { inseparable from the } \\
\text { approach to doing } \\
\text { business, which is } \\
\text { embodied into its mission } \\
\text { and values. }\end{array}$ & $\begin{array}{l}\text { Three strategic objectives are at the heart of the } \\
\text { company's sustainable development approach, } \\
\text { namely: } \\
\text { - Health and well-being } \\
\text { - Environmental protection } \\
\text { - Development of local communities }\end{array}$ & $\begin{array}{l}\text { The company seeks to work } \\
\text { in a responsible way by } \\
\text { means of engaging } \\
\text { stakeholders and } \\
\text { communities in support of } \\
\text { their } \\
\text { development. }\end{array}$ & $\begin{array}{l}\text { The company aims at } \\
\text { achieving strong } \\
\text { corporate governance } \\
\text { and leadership, as well } \\
\text { as transparent } \\
\text { reporting. }\end{array}$ \\
\hline
\end{tabular}

